\title{
Peertechz
}

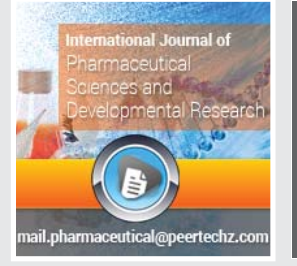

\section{Development and optimization of mucoadhesive microballons of nizatidine for management of peptic ulcer}

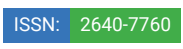
Pharmacy, Bhopal, MP 462045, India, Tel: 9893183369 . E-mail: drabhishek181281@gmail.com

Keywords: Mucoadhesive microballons; Nizatidine; Peptic ulcer; Gastroretentive system; Poly acrylic acid (PAA); Poly Vinyl Pyrrolidone (PVP)

https://www.peertechz.com

\section{Seema Jain ${ }^{1}$, Neha Jain², Mohan Lal Kor², Umesh Kumar Jain $^{3}$ and Abhishek Kumar Jain ${ }^{3 *}$}

1SSSIPS, RKDF University, Bhopal, MP 462033, India

${ }^{2}$ Vedica College of B. Pharmacy, RKDF University, Bhopal, MP 462033, India

${ }^{3}$ Bhopal Institute of Technology \& Science, Pharmacy, Bhopal, MP 462045, India

Check for updates

\begin{abstract}
The mucoadhesive microballons prepared by using combination of Poly Acrylic Acid (PAA), Poly Vinyl Pyrrolidone (PVP) polymers by polymer-polymer combination with solvent diffusion method. It is managing the discharge rate of Nizatidine between therapeutic absorption windows by extended the gastric emptying time of formulation. The delivery systems make certain accessibility of drug content at the assimilation site for the preferred period of time. The present work was justified effect of various parameters as polymer (PAA-PVP) concentration, drug concentration, internal phase/external phase ratio, surfactant concentration, stirring speed, stirring time. PAA-PVP polymeric combinations microballons were prepared by solvent dispersion technique. The effect of internal/external phase ratio on preparation of microballons shows that content of water in the internal phase played a key role in the formation of microballons. The particle size found to be decreased upon increasing the concentration of surfactant (span 80 ) in oil phase. This might be due to the increase the surface tension of aqueous phase which ultimately seem to allow the formation of micro size range. The present work confirmed that any criteria can be effect the result of the shape, size and size distribution, entire medication load of microballons.
\end{abstract}

\section{Introduction}

Ulcers are characterized histologically as a part in the mucosa of the GI tract through the muscularis mucosae into the submucosa or more inside part of GI trat mucous membrane. Ulcer can affect any part of the gastrointestinal tract contact with more secretion of acid peptic juices [1]. The gastric ulcer are generalized into Aphthous ulcers, Esophageal ulcers and Peptic ulcer based on their affected area in gastrointestinal tract in mouth, throat and stomach or the duodenum separately [2].

These are three kinds for example Aphthous ulcers create within the lips and cheeks or underneath the tongue. They are also called aphthae, aphthosis, aphthous stomatitis and infection. Mouth ulcers are generally have family ancestry (up to $40 \%$ ) and are ordinarily because of injury (in view of not appropriate fitting of false teeth, broke teeth, or fillings),anemia, measles, viral contamination, oral candidiasis, incessant diseases, throat malignant growth, mouth malignant growth and vitamin B deficiency [3,4]. Esophageal ulcers are injuries that happen toward the finish of throat because of Gastroesophageal Reflux Sickness (GERD) with $10 \%$ frequency. They can be produce pain directly underneath the breastbone $[5,6]$.

Peptic ulcer are chronic, frequently develop lesions that happen in any part of the gastrointestinal tract due to the more amount of secretion of acid peptic juices. Peptic ulcer develop in a number of part of the gastrointestinal tract (GIT) which is exposed to gastric acid and pepsin, for example the stomach and duodenum. Peptic ulcers generally induced in rodents by physiological, pharmacological or other surgical medicines which have etiological significance for stimulation of peptic ulcers. A few models are referenced in following which utilized 
tentatively for testing or assessing against peptic ulcer action of medications $[7,8]$.

o Stress ulcer through immobilization stress

o Ethanol induced mucosal damage in rats (cytoprotective activity)

o Sub-acute gastric ulcer in rats

o Gastric ischemia-reperfusion injury in rats

o Water-immersion stress or cold-water-restraint

o NSAIDs- (indomethacin, aspirin, and ibuprofen) induced gastric ulcers

o Acetic acid induced gastric ulcers

o Histamine induced gastric ulcers

o Reserpine induced gastric ulcers

o Serotonin induced gastric ulcers

o Pylorus-ligated-induced peptic ulcers

o Diethyl-dithio-carbamate (DDC)-induced pepticulcers

o Methylene blue-induced ulcers

o Ischemia-reperfusion induced gastric ulcers

o Cysteamine induced duodenal ulcers

o Indomethacin-histamine-induced duodenal ulcers

o Ferrous iron-ascorbic acid-induced gastric ulcers

o Acetic acid-H. pylori-induced ulcers [9-11].

There are atleast two main targets which could be used for anchoring of delivery system through mucoadhesive in the GIT, the mucosal tissue and mucosal gel layer. The mucos layer is the first surface encountered by particulate system and its complex structure offers many opportunities for the development of adhesive interaction with small polymeric particles either through non specific or specific interaction between complimentary structures. Due to all above advantages Microsphere delivery is an better choice for drug delivery in colon [12].

Microballons are small round particles; having diameter in the range of micrometer $(1 \mu \mathrm{m}$ to $1000 \mu \mathrm{m}$ or $1 \mathrm{~mm})$. Microballons are in also called as microparticles. Microballons are characterized as "the solid circles or API was spread all over the matrix or molecular dispersion of particles". Mucoadhesion is a term when outer layer of ballons adhere to the mucous layer of the mucosal surface. Mucoadhesion offers delayed retardent time at the absorption site, medication provide at a predefined site, enhance the release rate of drug because of increase contact time at mucosal surface of digestive tract. Mucoadhesion of balloons was developed by two different ways: starting contact between the surfaces or development of secondary bonds due to non covalent connection. Mucoadhesives must need preasence of mucin layer during the procedure of adhesion. Mucins are synthesized by globet cells and exocrine organs with mucin cells acnini. The mucus layer is the main surface for providing base to adhere the balloons for increase the retarding of drug release, thus will be effective for drug delivery through oral mucosa for peptic ulcer management [13-15].

\section{Material \& methods}

\section{Materials}

The drug nizatidine was generously supplied as a gift sample from Dr. Reddy Lab, Hydrabad, India. The polymers Polyacrylic acid ${ }^{\circledR}$ and Polyvinyl pyrrolidone $\mathrm{K}-30$ were procured from Himedia Laboratories Pvt. Ltd, Mumbai, India. The other chemical span $80^{\circledR}$ and $n$-hexane were purchased from $\mathrm{CDH}$ Pvt. Ltd. Mumbai, India. The Soya oil was purchased from local market of Bhopal M.P. (India).

\section{Methods}

Preformulation Study: Preformulation studies are needed to ensure the development of therapeutically effective and safe dosage form. It is characterize the physicochemical properties of drug substances and its interaction with various formulation components. Preformulation process is applied to secure the advancement of active treatment, viable and safe formulation development. It is consider as justify the physicochemical properties of API substances and its interaction with a range of formulation contents. The procured drug material was identified its originality by optimizing various parameters i.e. physical appearance, Melting point, $\mathrm{pH}$ indication, solubility profile in various aqueous and nonaqueous solvents, partition coefficient and FTIR study $[16,17]$.

\section{Solubility profile}

The solubility determination of nizatidine hydrochloride was carried out in various common solvents. A definite quantity (10 mg) of the drug was taken in a series of $25 \mathrm{ml}$ volumetric flasks and $10 \mathrm{ml}$ of each solvent was added to these flasks. The flasks were clamped and shaken in vortex shaker for 6 hours at room temperature till equilibrium. The flasks were observed visually for the presence of insoluble particle of drug. The supernatant was taken and filtered. Quantitative determination of nizatidine hydrochloride was carried out after suitable dilution using UV/Visible spectrophotometer (Shimadzu 1800, Japan). The experiment was repeated with the different volume of the solvents to obtain more appropriate degree of solubility $[16,17]$. The profile of solubility of nizatidine HcL in different solvent is given in Table 1.

\section{Partition coefficient}

Partition coefficient is determination of lipophilicity \& hydrophilicity of drugs. The parameter is useful to indicate ability of drug molecule to cross through bio-membranes. The parameter also defined as the ratio of unionised drug concentration in organic phase and aqueous phase during equilibrium. 


$$
\mathrm{P}_{\mathrm{o} / \mathrm{w}}=\frac{\mathrm{C}_{\text {oil }}}{\mathrm{C}_{\text {water }}} \text { at equilibrium }
$$

The partition coefficient of nizatidine hydrochloride was determined in $\mathrm{n}$-octanol/water mixture ( $\mathrm{pH}$ 7.0), and n-octanol/PBS (pH 7.4) [18].

Accurately weighed $10 \mathrm{mg}$ nizatidine hydrochloride drug dissolve in separating funnel containing $10 \mathrm{ml}$ each of $\mathrm{n}$-octanol and aqueous phase. It was placed on a vortex shaker for 6 hours until equilibrium of mixture was reached. The immiscible liquid phases were separated after some time and the aqueous phase was analysed for amount of drug after appropriate dilution with UV spectrophotometer. The results are presented in Table 2.

\section{FTIR spectrum of nizatidine hydrochloride}

The drug sample of nizatidine hydrochloride was identified by infrared spectroscopy (Alpha, Bruker, USA). The scanning was done using $\mathrm{KBr}$ dispersion pellet. The obtained spectrum of given sample is concordant with reference Figures 1,2. The spectral peaks assigned to various molecular vibrations are contained in Table 3 [18].

\section{Analytical method development of nizatidine hydrochlo- ride}

Hydrochloric acid Buffer (pH 1.2) Determination of absorption maxima $\left(\lambda_{\max }\right)$ : Standard stock solution of $10 \mu \mathrm{g} /$ ml with Hydrochloric acid Buffer ( $\mathrm{pH}$ 1.2) solution was scanned between 200-400 $\mathrm{nm}$ for the absorption maxima in a UV/visible spectrophotometer (Shimadzu 1800, Japan). The absorption maximum was obtained at $228 \mathrm{~nm}$ as shown in Figure 3.

Table 1: Solubility profile of nizatidine hydrochloride in different solvents at room temperature $\left(25 \pm 2^{\circ} \mathrm{C}\right)$

\begin{tabular}{c|c|c|} 
S. No. & Solvent (S) & Solubility indicator \\
\hline 1 & Distilled water & ++++ \\
2 & Ethanol (95\%) & +++ \\
3 & Methanol & +++ \\
4 & Isopropanol & + \\
5 & Ethyl acetate & + \\
6 & Dichloromethane & - \\
7 & Acetone & - \\
8 & Chloroform & - \\
9 & Toluene & ++++ \\
10 & PBS (pH7.4) & ++++ \\
11 & SIF (pH6.8) & ++++ \\
12 & Acetate buffer (pH5.0) & \\
+ ++++: Very-very soluble (less than 1 part) & \\
$++++:$ Freely soluble (1-10 parts) & \\
++ Sparingly soluble (30-100 parts) & \\
+ +: Slightly soluble (100-1000 parts) & \\
-: Practically insoluble (> 1000 parts) &
\end{tabular}

Table 2: Partition coefficient values of nizatidine hydrochloride.

\begin{tabular}{|c|c|c|}
\hline S. No. & Mixture of solvent & Partition coefficient (P) \\
\hline 1 & n-octanol / water & 0.2347 \\
\hline 2 & n-octanol / PBS (pH 7.4) & 0.2183 \\
\hline
\end{tabular}

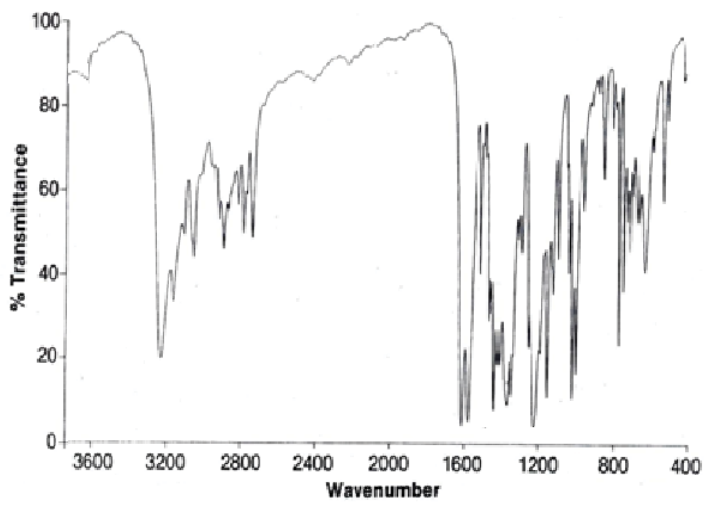

Figure 1: FTIR spectrum of nizatidine hydrochloride (I.P., 2004).

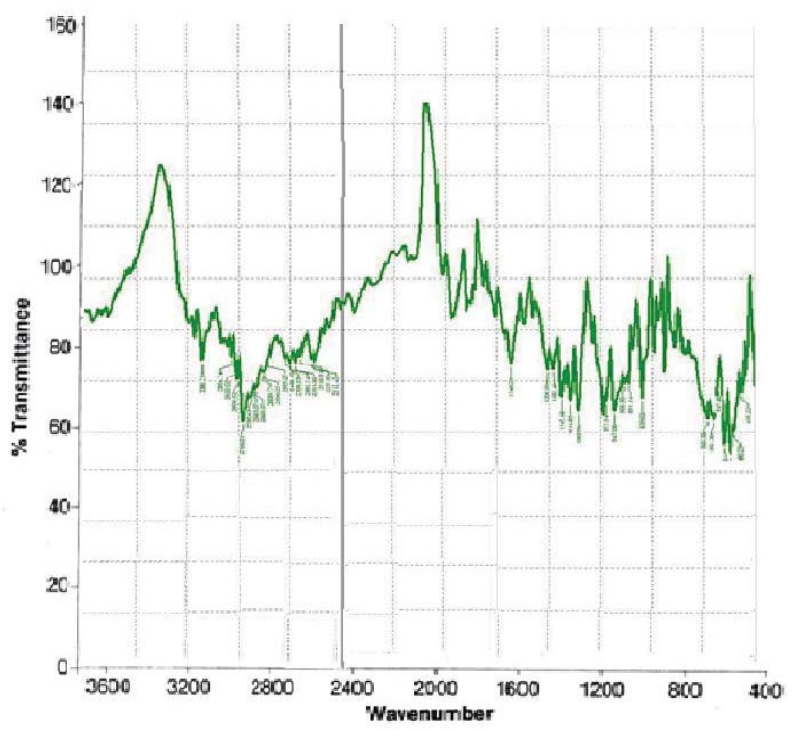

Figure 2: FTIR spectrum of nizatidine hydrochloride (Sample).

Table 3: Characteristic infrared absorption bands of nizatidine hydrochloride sample (wave number $\mathrm{cm}^{-1}$ ).

\begin{tabular}{|c|c|c|}
\hline S.No. & Wave No. $\left(\mathrm{cm}^{-1}\right)$ & Assignment \\
\hline 1. & 3280,3210 & $\mathrm{NH}$ stretch two groups \\
\hline 2. & 3107 & $\mathrm{CH}$ stretch, $\mathrm{NO}_{2}-\mathrm{CH}-$ \\
\hline 3. & 3094 & $\mathrm{CH}$ stretch, thiazole ring \\
\hline 4. & $\begin{array}{l}2945,2860,2829 \\
2784\end{array}$ & $\mathrm{CH}$ stretches, $\mathrm{NCH}_{3}, \mathrm{CH}_{2} \mathrm{CH}_{2}$ \\
\hline 5. & 1622 & $\mathrm{C}=\mathrm{C}$, conjugated with $\mathrm{NO}_{2}$ \\
\hline 6. & 1587 & $\mathrm{NO}_{2}$ stretch, conjugated with $\mathrm{C}-\mathrm{C}$, thiazole ring \\
\hline 7. & 1521 & Thiazole ring \\
\hline 8. & $\begin{array}{c}1470,1458,1435 \\
1422\end{array}$ & $\mathrm{CH}$ deformation in $\mathrm{NCH}_{3}, \mathrm{CH}_{2 ;} \mathrm{CN}$ stretch \\
\hline 9. & 1377,1359 & $\begin{array}{l}\text { Thiazole ring for one frequency is sys } \mathrm{NO}_{2}, \mathrm{H}- \\
\text { bonded, conjugated }\end{array}$ \\
\hline
\end{tabular}

Hydrochloric acid buffer ( $\mathrm{pH}$ 1.2) determination of calibration curve: The prepared stock solution was again diluted as aliquots of $0.2,0.4, \ldots . .1 .8,2.0 \mathrm{ml}$ with $10 \mathrm{ml}$ volumetric flasks and diluted to $10 \mathrm{ml}$ with Hydrochloric acid Buffer ( $\mathrm{pH}$ 1.2), thus get concentration range of $2-20 \mu \mathrm{g} / \mathrm{ml}$.

Citation: Jain S, Jain N, Kor ML, Jain UK, Jain AK (2020) Development and optimization of mucoadhesive microballons of nizatidine for management of peptic ulcer 
The different concentration solution was measured using spectrophotometer (Shimadzu 1800, Japan) at $\lambda_{\max } 228 \mathrm{~nm}$ and create the calibration curve (Table 4, Figure 4).

SIF (pH 6.8) determination of absorption maxima $\left(\lambda_{\max }\right)$ : Standard stock solution of $10 \mu \mathrm{g} / \mathrm{ml}$ with phosphate buffer (pH 6.8) was scanned between $200-400 \mathrm{~nm}$ for the absorption maxima by UV/visible spectrophotometer (Shimadzu 1800, Japan). The absorption maximum was obtained at $313 \mathrm{~nm}$ as shown in Figure 5.

SIF (pH 6.8) determination of calibration curve: The prepared stock solution was again diluted as aliquots of 0.2 , $0.4, \ldots . .1 .8,2.0 \mathrm{ml}$ with $10 \mathrm{ml}$ volumetric flasks and diluted to $10 \mathrm{ml}$ with simulated intestinal fluid ( $\mathrm{pH} 6.8$ ), thus get concentration range of $2-20 \mu \mathrm{g} / \mathrm{ml}$. The different concentration solution was measured using spectrophotometer (Shimadzu 1800, Japan) at $\max 313 \mathrm{~nm}$ and create the calibration curve (Table 5, Figure 6).

PBS (pH 7.4) determination of absorption maxima $\left(\lambda_{\max }\right)$ : Standard stock solution of $10 \mu \mathrm{g} / \mathrm{ml}$ with phosphate buffe (pH 7.4) was scanned between $200-400 \mathrm{~nm}$ for the absorption maxima by UV/visible spectrophotometer (Shimadzu 1800, Japan). The absorption maximum was obtained at $325 \mathrm{~nm}$ as shown in Figure 7.

PBS ( $\mathrm{pH}$ 7.4) determination of calibration curve: The prepared stock solution was again diluted as aliquots of 0.2 , $0.4, \ldots . .1 .8,2.0 \mathrm{ml}$ with $10 \mathrm{ml}$ volumetric flasks and diluted to

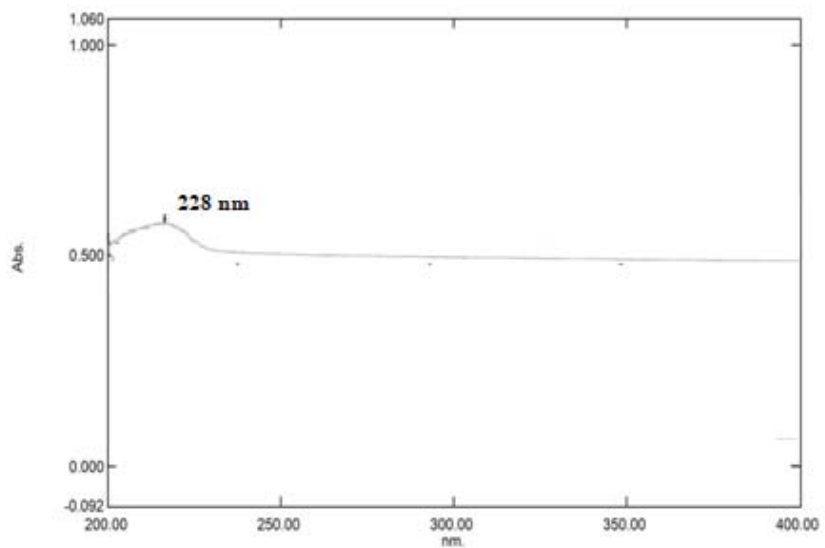

Figure 3: UV absorption maxima of nizatidine hydrochloride in Hydrochloric acid Buffer (pH 1.2) $\lambda_{\text {max }} 228 \mathrm{~nm}$.

Table 4: Calibration curve of nizatidine hydrochloride in Hydrochloric acid Buffer $(\mathrm{pH}$ 1.2) at $\lambda_{\max } 228 \mathrm{~nm}$.

\begin{tabular}{|c|c|c|c|}
\hline S. No & Concentration $(\mu \mathrm{g} / \mathrm{ml})$ & Absorbance & Statistical parameters \\
\hline 1 & 2 & 0.010 & \multirow{10}{*}{$\begin{array}{l}\text { Correlation coefficient: } \\
\qquad\left(R^{2}\right)=0.9951 \\
\text { Slope }(m)=0.0087 \\
\text { Intercept }(C)=-0.0008 \\
\text { Equation of line : } \\
y=0.0087 x-0.0008 \\
\text { Beer's law range: } \\
2-20(\mu \mathrm{g} / \mathrm{ml})\end{array}$} \\
\hline 2 & 4 & 0.025 & \\
\hline 3 & 6 & 0.038 & \\
\hline 4 & 8 & 0.052 & \\
\hline 5 & 10 & 0.072 & \\
\hline 6 & 12 & 0.092 & \\
\hline 7 & 14 & 0.112 & \\
\hline 8 & 16 & 0.141 & \\
\hline 9 & 18 & 0.159 & \\
\hline 10 & 20 & 0.169 & \\
\hline
\end{tabular}

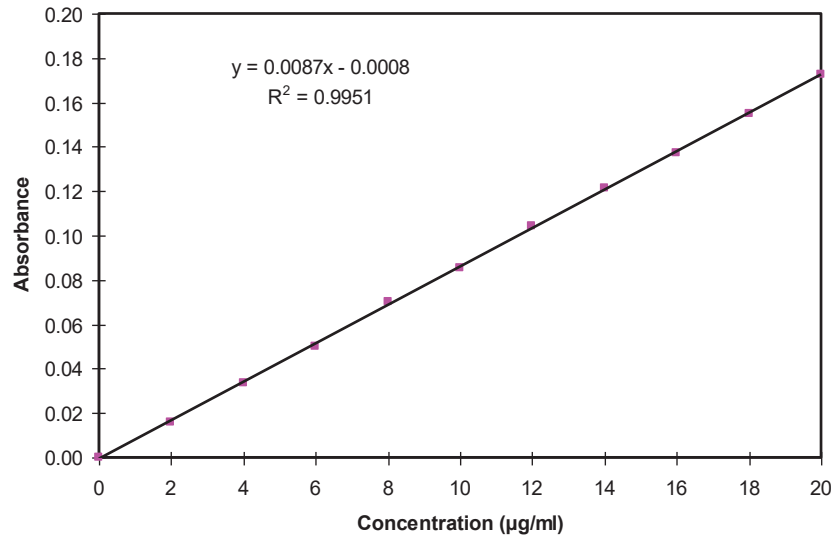

Figure 4: Calibration curve of nizatidine hydrochloride in phosphate buffer $(\mathrm{pH} 1.2)$.

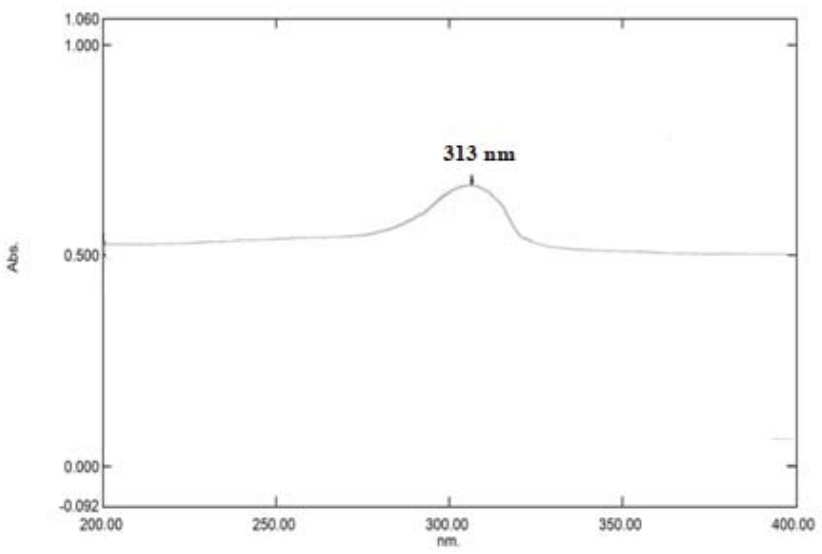

Figure 5: UV absorption maxima of nizatidine hydrochloride in SIF (pH 6.8) at $\lambda$ $313 \mathrm{~nm}$.

Table 5: Calibration curve of nizatidine hydrochloride in SIF (pH 6.8) at $\lambda$. $313 \mathrm{~nm}$.

\begin{tabular}{|c|c|c|c|}
\hline S. No & Concentration $(\mu \mathrm{g} / \mathrm{ml})$ & Absorbance & Statistical Parameters \\
\hline 1 & 2 & 0.101 & \multirow{8}{*}{$\begin{array}{l}\text { Correlation coefficient: } \\
\qquad\left(R^{2}\right)=0.9947 \\
\text { Slope }(m)=0.045 \\
\text { Intercept }(C)=0.0027 \\
\text { Equation of line: } \\
y=0.045 x+0.0027\end{array}$} \\
\hline 2 & 4 & 0.164 & \\
\hline 3 & 6 & 0.244 & \\
\hline 4 & 8 & 0.378 & \\
\hline 5 & 10 & 0.473 & \\
\hline 6 & 12 & 0.553 & \\
\hline 7 & 14 & 0.655 & \\
\hline 8 & 16 & 0.738 & \\
\hline 9 & 18 & 0.791 & \multirow[t]{2}{*}{ Beer's law range: $2-20(\mu \mathrm{g} / \mathrm{ml})$} \\
\hline 10 & 20 & 0.885 & \\
\hline
\end{tabular}

$10 \mathrm{ml}$ with phosphate buffer ( $\mathrm{pH} 7.4$ ), thus get concentration range of $2-20 \mu \mathrm{g} / \mathrm{ml}$. The different concentration solution was measured using spectrophotometer (Shimadzu 1800, Japan) at $\lambda_{\max } 325 \mathrm{~nm}$ and create the calibration curve (Table 6, Figure 8) [19].

Preparation of PAA-PVP mucoadhesive microballons: The mucoadhesive microballons were prepared by intermolecular complex formation and solvent diffusion method with concentration variables. Poly acrylic acid ${ }^{\circledR}$ (PAA) $1 \mathrm{~g}$ and Poly vinyl pyrrolidone $\mathrm{K}-30$ (PVP) $0.2 \mathrm{~g}$ was dissolved in $5 \mathrm{ml}$ of solvent mixture of ethanol/water $(7: 3 \mathrm{v} / \mathrm{v})$ [14]. The drug amount $40 \mathrm{mg}$ was dissolved in polymeric combination. The

Citation: Jain S, Jain N, Kor ML, Jain UK, Jain AK (2020) Development and optimization of mucoadhesive microballons of nizatidine for management of peptic ulcer Int J Pharm Sci Dev Res 6(1): 021-029. DOI: https://dx.doi.org/10.17352/ijpsdr.000030 
drug polymer solution was successively dropped down using a syringe, into of soya oil with $(1.5 \% \mathrm{v} / \mathrm{v}) \operatorname{span} 80^{\circledR}$. The resultant solution was stirred with a magnetic stirrer (Remi, India) at $500 \mathrm{rpm}$ at an ambient temperature for $4 \mathrm{~h}$. The prepared microballons were gradually hardened with a time of drying period and collected by washed three times with $n$-hexane and dried at room temperature.

\section{Identification of variables of PVA-PAA mucoadhesive microballons}

Formulation and process variables: The microballons were prepared by a number of variables of formulation parameters. The number of process variables i.e. polymer and drug concentration, phase volume ratio, surfactant concentration, stirring time and stirring speed which could affect the preparation and properties of microballons were also studied.

Polymer combination (PVP-PAA) concentration: The combination of PVP-PAA concentration were studied by preparation of microballons with varying the concentration of PVP i.e. $0.1: 1 \%, 0.2: 1 \%, 0.3: 1 \%$ and $0.4: 1 \% \mathrm{w} / \mathrm{v}$ in constant concentration of PAA polymer. The effect of average particle size and shape were recorded and shown in Table 7 and Figure 9 under consideration of result.

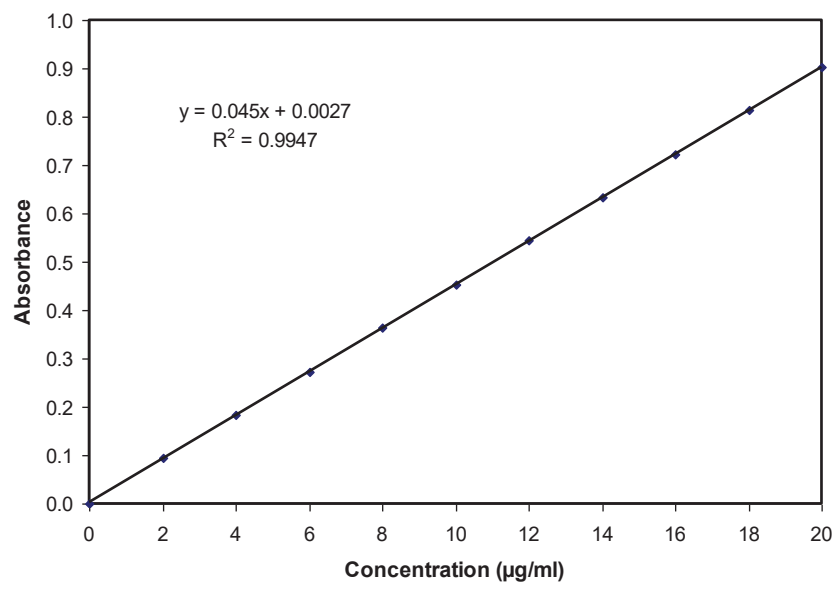

Figure 6: Calibration standard curve of nizatidine hydrochloride in SIF (pH 6.8)

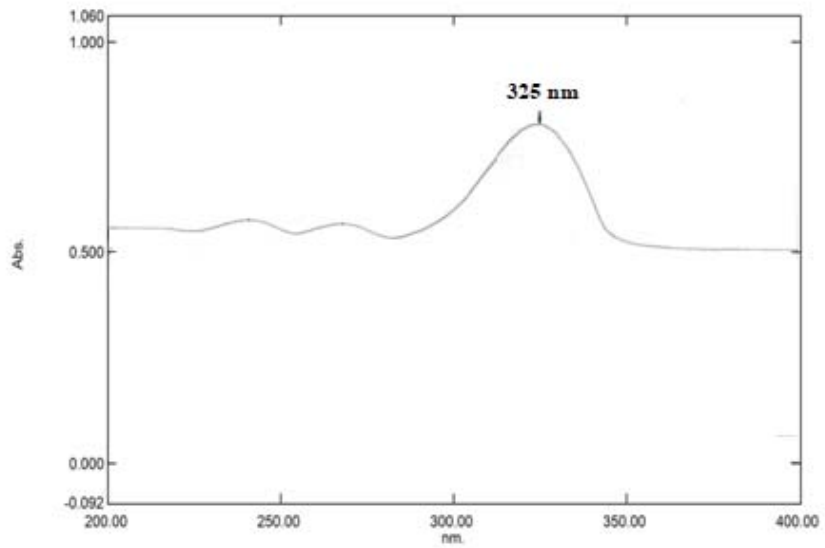

Figure 7: UV absorption maxima of nizatidine hydrochloride in PBS (pH 7.4) at $325 \mathrm{~nm}$.
Table 6: Calibration curve of nizatidine hydrochloride in Phosphate buffer ( $\mathrm{pH} 7.4)$ at $\lambda_{\max } 325 \mathrm{~nm}$.

\begin{tabular}{|c|c|c|c|}
\hline S. No & Concentration $(\mu \mathrm{g} / \mathrm{ml})$ & Absorbance & Statistical [Parameters \\
\hline 1 & 2 & 0.055 & \\
\hline 2 & 4 & 0.094 & Correlation coefficient: \\
\hline 3 & 6 & 0.140 & $\left(\mathrm{R}^{2}\right)=0.9934$ \\
\hline 4 & 8 & 0.194 & Slope $(\mathrm{m})=0.0268$ \\
\hline 5 & 10 & 0.267 & \\
\hline 6 & 12 & 0.323 & Intercept $(\mathrm{C})=0.0008$ \\
\hline 7 & 14 & 0.378 & \\
\hline 8 & 16 & 0.406 & Equation of line: \\
\hline 9 & 18 & 0.479 & $\mathrm{y}=0.0268 \mathrm{x}+0.0008$ \\
\hline 10 & 20 & 0.564 & \\
\hline
\end{tabular}

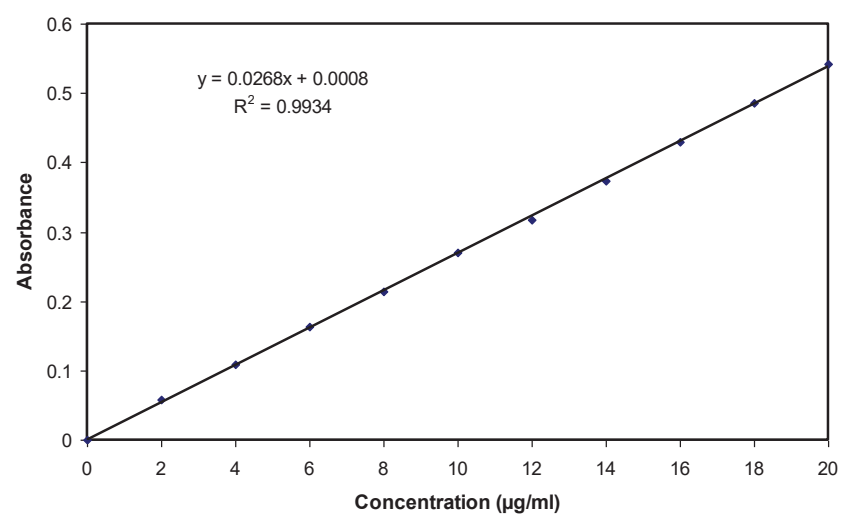

Figure 8: Calibration curve of nizatidine hydrochloride in PBS (pH 7.4).

Table 7: Effect of PVP-PAA concentration on particle size and Shape of microballons

\begin{tabular}{|c|c|c|c|}
\hline $\begin{array}{c}\text { Formulation } \\
\text { code }\end{array}$ & $\begin{array}{c}\text { Polymer (PVP-PAA) } \\
\text { concentration }(\% \mathrm{~W} / \mathrm{V})\end{array}$ & $\begin{array}{c}\text { Particle size } \\
(\boldsymbol{\mu m})\end{array}$ & \begin{tabular}{c} 
Particle Shape \\
\hline $\mathrm{P}_{1}$
\end{tabular} \\
\hline $\mathrm{P}_{2}$ & $0.1: 1$ & $108.42 \pm 2.41$ & $\begin{array}{c}\text { Circular with smooth } \\
\text { surface }\end{array}$ \\
\hline $\mathrm{P}_{3}$ & $0.2: 1$ & $116.23 \pm 1.83$ & Nearly circular \\
\hline $\mathrm{P}_{4}$ & $0.4: 1$ & $140.33 \pm 2.51$ & Deformed \\
\hline Mean $\pm \mathrm{SD}(\mathrm{n}=3)$ & & & \\
\hline
\end{tabular}

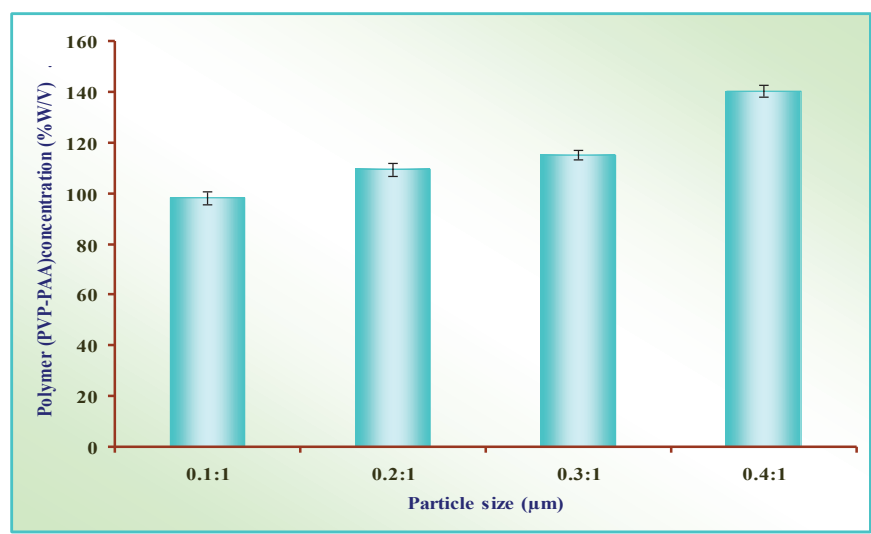

Figure 9: Effect of PVP-PAA concentration on particle size and drug entrapment efficiency of microballons.

Effect of drug concentration: The effect of drug concentration was identified by prepared microballons with varying percentage of drug concentration viz. 20:100, 40:100,

Citation: Jain S, Jain N, Kor ML, Jain UK, Jain AK (2020) Development and optimization of mucoadhesive microballons of nizatidine for management of peptic ulcer Int J Pharm Sci Dev Res 6(1): 021-029. DOI: https://dx.doi.org/10.17352/ijpsdr.000030 
$60: 100,80: 100 \% \mathrm{w} / \mathrm{w}$ of drug while weight of polymer was remain constant. The result was optimized on the basis of drug entrapment efficiency and particle size of microballons. The observations are showed in Table 8 and graphically shown in Figure 10.

Effect of internal phase/external phase ratio: The effect of internal/external phase ratio was justified by selection of P2D2 formulation. The microballons were prepared with change of ratio 1:1, 1:5 and 1:10 of both internal and outer phase ratio as constant parameter. The effect of phase ratio on the particle size and percentage drug entrapment efficiency is reported in Table 9 and shown in Figure 11.

Effect of surfactant concentration: The effect of surfactant (span-80) concentrations was optimized on selected formulation P2D2I2. Microballons were prepared using different surfactant concentrations in external phase. The effect of surfactant concentration formulation is reported in Table 10 and shown in Figure 12.

Effect of stirring speed: The effect of stirring speed was optimized by selection of formulation (P2D2I2E3). The microballons were prepared by taking varying stirring speed i.e. $300,400,500$ and $600 \mathrm{rpm}$ (Remi, India) and other variables remain constant. The optimization was done on the basis

Table 8: Effect of drug concentration on particle size and drug entrapment efficiency of microballons.

\begin{tabular}{|c|c|c|c|}
\hline $\begin{array}{c}\text { Formulation } \\
\text { code }\end{array}$ & $\begin{array}{c}\text { Drug amount (\% of polymer } \\
\text { weight) }\end{array}$ & $\begin{array}{c}\text { Particle size } \\
(\boldsymbol{\mu m})\end{array}$ & $\begin{array}{c}\% \text { Drug } \\
\text { loading }\end{array}$ \\
\hline P2D1 & 20 & $107.41 \pm 1.82$ & $78.52 \pm 1.62$ \\
\hline P2D2 & 40 & $112.42 \pm 2.52$ & $92.41 \pm 1.81$ \\
\hline P2D3 & 60 & $119.21 \pm 2.82$ & $80.33 \pm 1.52$ \\
\hline P2D4 & 80 & $124.23 \pm 3.12$ & $71.42 \pm 2.45$ \\
\hline
\end{tabular}

Mean SD $\pm(n=3)$

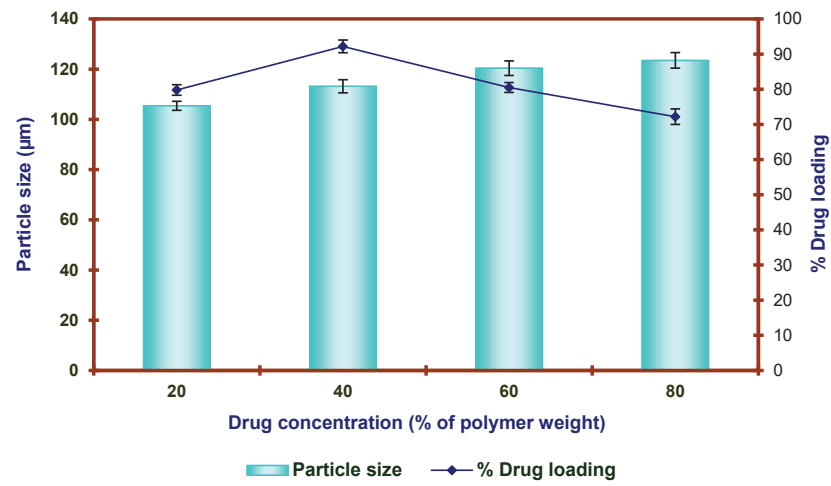

Figure 10: Effect of Nizatidine concentration (\% of polymer weight) on particle size and drug entrapment efficiency of microballons.

Table 9: Effect of Phase ratio on particle size and drug loading.

\begin{tabular}{|c|c|c|c|}
\hline $\begin{array}{c}\text { Formulation } \\
\text { code }\end{array}$ & Phase ratio & $\begin{array}{c}\text { Particle size } \\
(\boldsymbol{\mu} \mathrm{m})\end{array}$ & $\begin{array}{c}\text { Percentage drug entrapment } \\
\text { efficiency }\end{array}$ \\
\hline P2D2I1 & $1: 1$ & $103.6 \pm 1.6$ & $84.51 \pm 3.22 \%$ \\
\hline P2D2I2 & $1: 5$ & $109.4 \pm 2.5$ & $93.13 \pm 2.52 \%$ \\
\hline P2D2I3 & $1: 10$ & $115.3 \pm 1.8$ & $74.25 \pm 1.54 \%$ \\
\hline
\end{tabular}

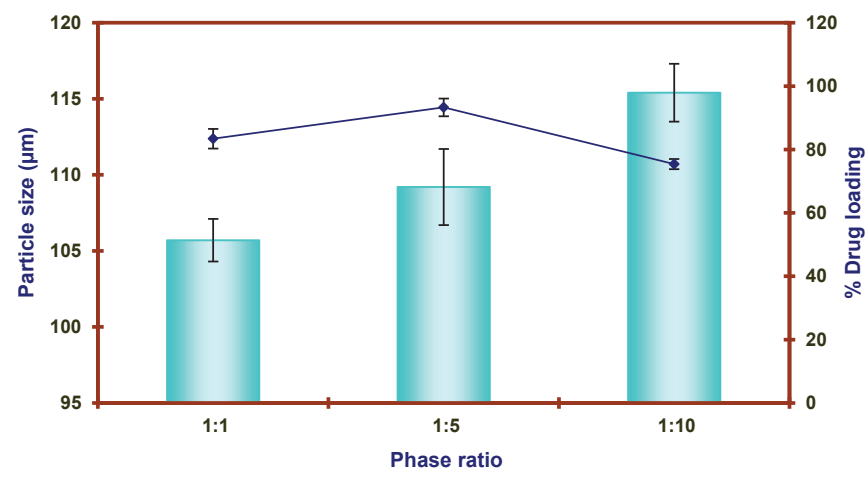

$\rightleftarrows$ Particle size $\longrightarrow$ ๑ Drug loading

Figure 11: Effect of solvent ratio on particle size and drug entrapment efficiency.

Table 10: Effect of surfactant concentration on particle size and drug loading.

\begin{tabular}{|c|c|c|c|}
\hline $\begin{array}{c}\text { Formulation } \\
\text { code }\end{array}$ & $\begin{array}{c}\text { Surfactant } \\
\text { conc. } \\
(\% \mathbf{V} / \mathbf{V})\end{array}$ & $\begin{array}{c}\text { Particle size } \\
(\boldsymbol{\mu m})\end{array}$ & $\begin{array}{c}\text { Percentage drug entrapment } \\
\text { efficiency }\end{array}$ \\
\hline P2D2I2E1 & 0.5 & $128.32 \pm 2.71$ & $77.15 \pm 3.11 \%$ \\
\hline P2D2I2E2 & 1.0 & $119.22 \pm 3.21$ & $81.03 \pm 3.02 \%$ \\
\hline P2D2I2E3 & 1.5 & $113.25 \pm 2.34$ & $92.81 \pm 1.54 \%$ \\
\hline P2D212E4 & 2.0 & $108.23 \pm 3.15$ & $79.05 \pm 1.08 \%$ \\
\hline
\end{tabular}

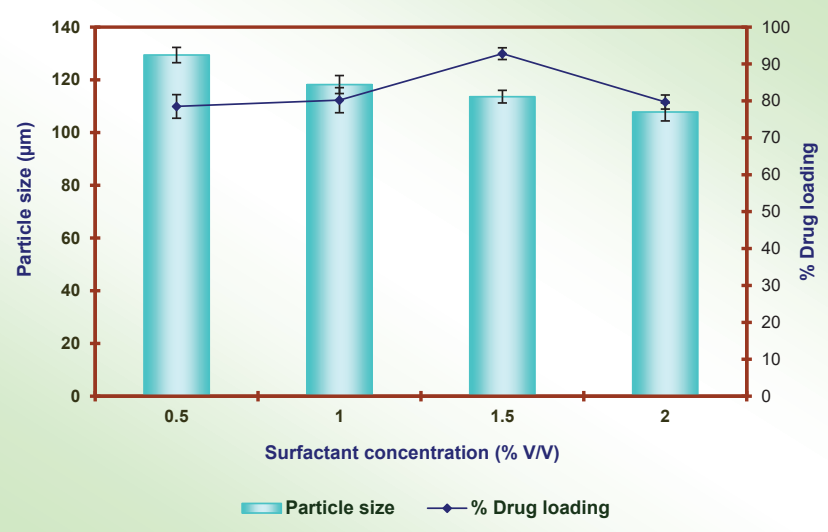

Figure 12: Effect of surfactant concentration on particle size and drug entrapment efficiency.

of average particle size and maximum \% drug entrapment efficiency. The observations are recorded and shown in Table 11 and Figure 13.

Effect of stirring time: The effect of stirring time was justified by selection of formulation (P2D2I2E3S3). The microballons were prepared by varying stirring time i.e. $1 \mathrm{~h}, 2 \mathrm{~h}, 3 \mathrm{~h}$ and $4 \mathrm{~h}$ and other variables remain constant. The optimization was justified on the basis of average particle size and maximum \% drug entrapment efficiency. The observations are recorded and shown in Table 12 and Figure 14.

\section{Results and discussion}

The drug nizatidine hydrochloride is white to off white amorphous powder and the melting point was at $132^{\circ} \mathrm{C}$. The $\mathrm{pH}$ of $1.0 \% \mathrm{w} / \mathrm{v}$ solution of nizatidine hydrochloride in carbon dioxide free water was measured at $25 \pm 1^{\circ} \mathrm{C}$ using a $\mathrm{pH}$ meter 


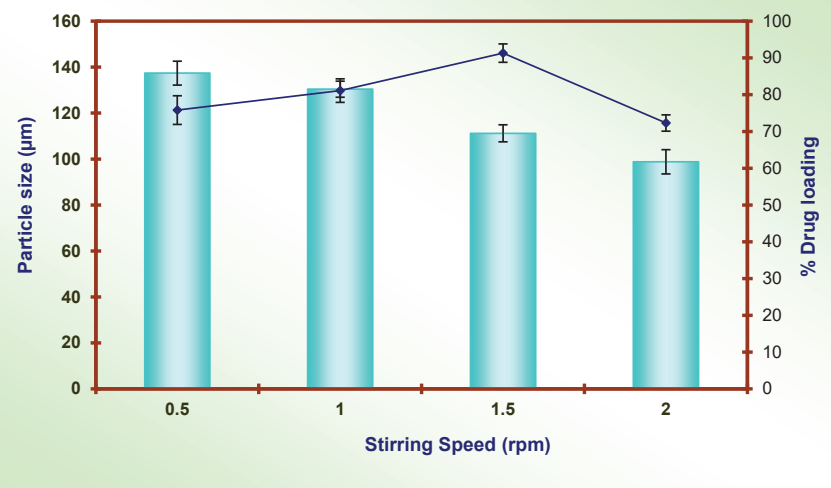

$\square$ Particle size $\rightarrow$ \% Drug loading

Figure 13: Effect of stirring speed on particle size and drug entrapment efficiency.

Table 11: Effect of stirring speed on particle size and drug loading.

\begin{tabular}{|c|c|c|c|}
\hline $\begin{array}{c}\text { Formulation } \\
\text { code }\end{array}$ & $\begin{array}{c}\text { Speed } \\
(\mathbf{r p m})\end{array}$ & $\begin{array}{c}\text { Particle size } \\
(\boldsymbol{\mu m})\end{array}$ & $\begin{array}{c}\text { Percentage drug entrapment } \\
\text { efficiency }\end{array}$ \\
\hline P2D2I2E3S1 & 300 & $135.02 \pm 5.31$ & $74.15 \pm .3 .18 \%$ \\
\hline P2D212E3S2 & 400 & $128.24 \pm 3.51$ & $83.02 \pm 3.15 \%$ \\
\hline P2D212E3S3 & 500 & $110.32 \pm 3.25$ & $90.03 \pm 3.05 \%$ \\
\hline P2D212E3S4 & 600 & $99.25 \pm 5.21$ & $73.24 \pm 2.12 \%$ \\
\hline
\end{tabular}

Table 12: Effect of stirring time on particle size and drug entrapment efficiency of microballons.

\begin{tabular}{|c|c|c|c|}
\hline $\begin{array}{c}\text { Formulation } \\
\text { code }\end{array}$ & $\begin{array}{c}\text { Stirring Time } \\
(\mathbf{h r s})\end{array}$ & $\begin{array}{c}\text { Particle size } \\
(\boldsymbol{\mu m})\end{array}$ & $\begin{array}{c}\text { \% Drug entrapment } \\
\text { efficiency }\end{array}$ \\
\hline P2D2I2E3S3T1 & 1 & $137.15 \pm 2.25$ & $66.17 \pm 2.05$ \\
\hline P2D2I2E3S3T2 & 2 & $128.23 \pm 1.81$ & $72.11 \pm 2.51$ \\
\hline P2D2I2E3S3T3 & 3 & $118.05 \pm 2.05$ & $82.05 \pm 1.51$ \\
\hline P2D2I2E3S3T4 & 4 & $107.05 \pm 1.61$ & $91.06 \pm 2.14$ \\
\hline
\end{tabular}

Mean SD $\pm(n=3)$

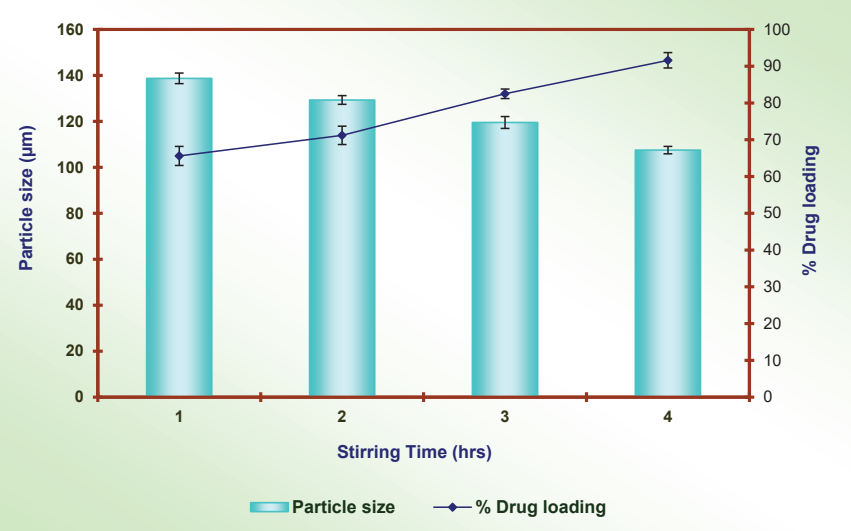

Figure 14: Effect of stirring time on particle size and drug loading in PAA-PVP microballons.

which was found to be 5 . The drug was identified by the official method (I.P., 1996). The solubility of the drug was determined in various solvents at room temperature. Among the solvents used, highest solubility of drug was found in aqueous, meth. and eth. $95 \%$. The drug was slightly soluble in ethyl acetate and isopropanolol. It was practically insoluble in chloroform and dichloromethane. The partition coefficient of nizatidine hydrochloride in $\mathrm{n}$-octanol/distilled water ( $\mathrm{pH} 7.0$ ) was 0.2347 and in $\mathrm{n}$-octanol/PBS ( $\mathrm{pH} 7.4$ ) 0.2183 respectively. Partition coefficient value of drug also revealed its polar and hydrophilic nature. The analytical study was performed by using UV spectrophotometery of nizatidine hydrochloride at $\lambda_{\max } 228$ $\mathrm{nm}$ for hydrochloric acid buffer ( $\mathrm{pH} 1.2), 313 \mathrm{~nm}$ for SIF $(\mathrm{pH}$ 6.8) and $325 \mathrm{~nm}$ for PBS ( $\mathrm{pH} \mathrm{7.4)}$ ) and result was found to be reproducible and highly sensitive. The calibration curves were performed for quantitative analysis of nizatidine hydrochloride and absorbance are given in Tables 4-6 graphically shown in Figures 4-8. It was found that all result of analytical validation method follow Beer's law by the statistical analysis. The result was found as correlation coefficient greater than 0.999 in all the cases and hence it was quite linear in nature. Hence it could be concluded that the estimation procedure is quick, convenient, fairly reliable, sensitive, less expensive and reproducible.

In the present study polymer were selected on the basis of their non-interference in the estimation of drugs. The absorbance data of nizatidine hydrochloride with different additives in PBS (pH 7.4) are shown in Table 6. The absorbance data had shown no appreciable interference of polymers in the estimation of nizatidine hydrochloride. PAA-PVP complexed microballons were prepared by solvent dispersion method. The PAA and PVP solution were dispersed in external phase. Soya oil was selected as the external phase since the ethanol/water combination as an internal phase is not miscible with soya oil so composite was not soluble in it. The PAA droplets formed collid with PVP solution in soya oil to form interpolymer composite. The microballons of PAA/PVP composite slowly solidified and hardened due to ethanol and water was diffused out through internal phase. PAA is measured as one of the best mucoadhesive polymers. The PAA and PVP combined and thickening out in ethanol and water mixture within short period of time to form PVP/PAA interpolymer composite, thus prepare mucoadhesive microballons. The outcome of formulation variables e.g. Polymer mixing ratio, drug concentration, internal/external phase ratio, surfactant concentration and process variables e.g. stirring speed and stirring time were calculated. The results suggested that these variables influence the shape, size and size distribution, total drug loading efficiency and in vitro drug release of the final preparation. Hence these parameters were optimized to obtain microballons with narrow size distribution and maximum drug loading efficiency. The microscopic examination of microballons revealed that the mean diameter of PAA-PVP complexed microballons varied from $98.21 \pm 2.51 \mu \mathrm{m}$ to $140.31 \pm 2.51 \mu \mathrm{m}$ on varying the concentration of polymers (PAA-PVP) from $0.51 \%$ to $2.1 \%$. The average particle size of microballons increased with increasing polymers concentration and the shape of microballons varied from circular and rough to deform.

As the shape was circular and smooth with P2 formulation and the size of microballons was also sufficiently low (108.42 \pm 2.41$)$, this formulation was considered optimum and selected for further study (Table 7 \& Figure 9).

The effect of concentration of drug was justified by the identified variation in average particle size and maximum 
entrapment efficiency. The PAA-PVP ratio was varied during preparation of microballons in different concentration of nizatidine viz. 20, 40, 60 and $80 \mathrm{mg} / 100 \mathrm{mg}$ of PAA-PVP. The result was observed that with increasing the drug concentration, the entrapment efficiency of drug in microballons were also increased up to $40 / 100 \mathrm{mg}$. If the concentration of drug was increased more than $40 / 100 \mathrm{mg}$, the entrapment efficiency gradually decreased. This was due to saturation of PAA-PVP with the drug and the particle size of microballons does not significantly change. The observation recorded in Table 8 and shown in Figure 10.

The effect of internal/external phase ratio on preparation of microballons showed that amount of water act as internal phase was effected. The mixing amount of ethanol starts to diffused out into the oil phase, and water act as important part for preparation core of the emulsion droplets. The result was justified that, the content of water directly affects the solidification time of the microballons. If the phase volume ratio was selected more than $1: 5$, the solidification time of the microballons increased. This was due to the using relatively large quantity of oil phase during mixing. This was decreased the collision frequency between the incompletely solidified microballons (Table 9 and Figure 11).

The particle size of microballons was decreased, while increasing the concentration of surfactant (span 80) in oil phase. The surface tension of aqueous phase was increased, this allow the formation of micro size range. The optimum size of microballons was $112.6 \pm 2.5 \mu \mathrm{m}$ and drug entrapment efficiency was $92.4 \pm 1.8 \%$ at using $1.5 \% \mathrm{v} / \mathrm{v}$ surfactant concentration. As the amount of surfactant increased the particle size of microballons was decreased due to formation of micelles The drug entrapment efficiency also decreased because of the leaching out of the drug particles during optimization process (Table 10 and Figure 12).

The effect of stirring speed was identified by increasing speed from 300 to $500 \mathrm{rpm}$. The average particle size was decreased from $135.2 \mu \mathrm{m}$ to $99.5 \mu \mathrm{m}$, because of more stirring speed enhances the energy, and thus breaks up the emulsion droplets and formed small droplets. The result was concluded that as stirring speed increases, an average particle size of microballons was decreased. At $500 \mathrm{rpm}$ formulation P2D2I2E3S3 shaped narrowest size distribution $110.2 \pm 3.5 \mu \mathrm{m}$ with spherical shape with drug entrapment efficiency was $90.3 \pm 3.5 \%$. The observation documented in Table 11 and showed in Figure 13.

The average particle size of PVP-PAA microballons reduces with increasing stirring time during mixing. Narrow particle size was found $107.5 \pm 1.6 \mu \mathrm{m}$ with entrapment efficiency $91.6 \pm 2.1 \%$ of formulation $\mathrm{P} 2 \mathrm{D} 2 \mathrm{I} 2 \mathrm{E} 3 \mathrm{~S} 3 \mathrm{~T} 4$ after $4 \mathrm{~h}$ stirring time duration. Stirring time for more than $4 \mathrm{~h}$ origin separation of aqueous phase, thus agglomeration of the polymers was produced. The observations are recorded in Table 12 and shown in Figure 14.

\section{Conclusion}

Mucoadhesive microballons is one of dosage forms, which make available the opportunity of increase the bioavailability. The present study was concluded that the prepared mucoadhesive microballons was advanced example of current formulation by solvent dispersion technique. The present work was justified the effect of various parameters as polymer combination and its concentration (PVP-PAA), drug concentration, internal phase/external phase ratio, surfactant concentration, stirring speed, stirring time. The polymeric mixture was mixed in oil then this mixture stirred in a blend of ethanol/water mixture. The interpolymer complex beads start to solidified and convert to hardening material as ethanol water mixture diffused out. The concentration of drug the entrapment efficiency gradually changed. The effect of internal/external phase ratio as internal phase played a key role in the formation of microballons. The particle size found to be decreased as the ratio of surfactant (span 80) change as surface tension of aqueous phase allow the formation of micro size balloons. The stirring speed decreased the particle size with enhancing the stirring time to format agglomeration of the polymers. The outcomes proposed that these factors confirm impact on the shape, size and size distribution, entire medication load effectiveness of microballons.

\section{References}

1. Kumar V, Abbas AK, Fausto N (2006) Robbins and Cotran Pathologic basis of disease. 7th edition. New Delhi: Elsevier India Private Limited.

2. Kumar A, Singh R, Sharma R, Kumar S (2012) Peptic ulcer: a review on etiology and pathogenesis. International Research Journal of Pharmacy 3: 34-38. Link: https://bit.ly/2CTZKjC

3. Subiksha PS (2014) Various remedies for recurrent Aphthous ulcer: a review. Journal of Pharmaceutical Science and Research 6: 251-253. Link: https://bit.ly/3gkgdfD

4. Crispian S, Meir G, Francina L (2003) The diagnosis and management of recurrent Aphthous Stomatitis. J Am Dent Assoc 134: 200-207. Link: https://bit.ly/3g81lk7

5. Higuchi D, Choichi S, Shah SS, Satoshi T, Charles EL (2003) Etiology, treatment and outcome of esophageal ulcers: A 10 year experience in an urban emergency hospital. J Gastrointest Surg 7: 836-842. Link: https://bit.ly/3g2BFFA

6. Mohan H (2013) Text book of Pathology. 6th edition. New Delhi: Jaypee Brothers Medical Publisher (P) Ltd

7. Michael BA, Charles A, Isaac G, Alexander N (2013) in-vivo models used for evaluation of potential anti-gastroduodenal ulcer agents. Ulcers 1-12. Link: https://bit.ly/3fasAJw

8. Vogel HG (2002) Discovery and evaluation, Pharmacological assays. $2^{\text {nd }}$ edition. Berlin: Springer Publication 228-289.

9. Sreenivas SA, Pai KV (2009) Synthesis of thiolated Chitosan : promising polymers for prolong mocoadhesive drug delivery. Int J Pharm 1: 670-678. Link: https://bit.ly/305W4Eh

10. Rutkowski S, Si T, Gai M, Frueh J, He Q (2018) Hydrodynamic electrospray ionization jetting of calcium alginate particles: effect of spray-mode spraying distance and concentration. RSC Advances 8: 24243-24249. Link: https://rsc.li/3f68LDo

11. Rutkowski S, Mu L, Si T, Gai M, Sun M, et al. (2019) Magnetically-propelled hydrogel particle motors produced by ultrasound assisted hydrodynamic electrospray ionization jetting. Colloids and Surfaces B. Biointerfaces 175 44-55. Link: https://bit.ly/32YeSXX

Citation: Jain S, Jain N, Kor ML, Jain UK, Jain AK (2020) Development and optimization of mucoadhesive microballons of nizatidine for management of peptic ulcer. Int J Pharm Sci Dev Res 6(1): 021-029. DOI: https://dx.doi.org/10.17352/ijpsdr.000030 
12. Li W, Gai M, Rutkowski S, He W, Meng S, et al. (2018) An Automated Device for Layer-by-Layer Coating of Dispersed Superparamagnetic Nanoparticle Templates. Colloid Journal 80: 648-659. Link: https://bit.ly/3jMQZbL

13. Gennaro AR (1990) In: Remington pharmaceutical sciences, $18^{\text {th }}$ edition, Mack publishing company, Pennsylavania, USA.

14. Leo A, Hansch C, Elkins D (1971) Partition coefficients and their uses. Chem Rev 525-621. Link: https://bit.ly/3hNnLYx

15. Chun MK, Cho CS, Choi HK (2001) A novel mucoadhesive polymer prepared by template polymerization of acrylic acid in the presence of poloxamer. $\mathrm{J} \mathrm{Appl}$ Polym Sci 79: 1525-1530. Link: https://bit.ly/39BEhYt

16. Jain AK, Jain CP, Gaur K, Kakde A, Meena M, et al. (2009) Effect of natural biodegradable and synthetic polymer for gastric disease by floating microballons. Continental J Pharm Sci 3: 1-6. Link: https://bit.ly/32ZBYxi

17. Jain AK, Jain CP, Tanwar YS, Naruka PS (2009) Formulation, characterization and in vitro evaluation of floating microballons of famotidine as a gastro retentive dosage form. Asi $\mathrm{J}$ of Pharmac 3: 222-226. Link: https://bit.ly/3f57AUz

18. Jain AK, Jain CP, Jain N, Bishnoi RS (2014) Enhancement the dissolution profile of ciprofloxacin and metronidazole with -cyclodextrin and acidic solubilizing additives. WJPPS 2: 540-551.

19. Jain N, Kori ML, Jain AK (2018) Pectin and Its Combination with Different Polymers for Colon-Targeted Drug Delivery: A Review. Inventi Rapid: NDDS 1: $1-8$.

\section{Discover a bigger Impact and Visibility of your article publication with}

\section{Peertechz Publications}

\section{Highlights}

* Signatory publisher of ORCID

* Signatory Publisher of DORA (San Francisco Declaration on Research Assessment)

* Articles archived in worlds' renowned service providers such as Portico, CNKI, AGRIS, TDNet, Base (Bielefeld University Library), CrossRef, Scilit, J-Gate etc.

* Journals indexed in ICMJE, SHERPA/ROMEO, Google Scholar etc.

* OAI-PMH (Open Archives Initiative Protocol for Metadata Harvesting)

* Dedicated Editorial Board for every journal

* Accurate and rapid peer-review process

* Increased citations of published articles through promotions

* Reduced timeline for article publication

Submit your articles and experience a new surge in publication services (https://www.peertechz.com/submission).

Peertechz journals wishes everlasting success in your every endeavours.

Copyright: ( 2020 Jain S, et al. This is an open-access article distributed under the terms of the Creative Commons Attribution License, which permits unrestricted use, distribution, and reproduction in any medium, provided the original author and source are credited.

Citation: Jain S, Jain N, Kor ML, Jain UK, Jain AK (2020) Development and optimization of mucoadhesive microballons of nizatidine for management of peptic ulcer Int J Pharm Sci Dev Res 6(1): 021-029. DOI: https://dx.doi.org/10.17352/ijpsdr.000030 